\title{
Evaluation of water quality at the source of streams of the Sinos River Basin, southern Brazil
}

\author{
Benvenuti, T. ${ }^{a *}$, Kieling-Rubio, MA. ${ }^{b}$, Klauck, $C R .^{c}$ and Rodrigues, MAS. ${ }^{c}$ \\ ${ }^{a}$ Laboratório de Corrosão, Proteção e Reciclagem de Materiais - LACOR, Universidade Federal do Rio Grande do Sul - \\ UFRGS, Avenida Bento Gonçalves, 9500, CEP 91501-970, Porto Alegre, RS, Brazil \\ bLaboratório de Botânica, Programa de Pós-Graduação Mestrado em Qualidade Ambiental, Universidade Feevale, \\ Rodovia RS-239, 2755, Vila Nova, CEP 93352-000, Novo Hamburgo, RS, Brazil \\ 'Programa de Pós-Graduação Mestrado em Qualidade Ambiental, Universidade Feevale, \\ Rodovia RS-239, 2755, Vila Nova, CEP 93352-900, Novo Hamburgo, RS, Brazil \\ *e-mail: benvenuti.tatiane@gmail.com
}

Received: May 24, 2013 - Accepted: July 24, 2013 - Distributed: May 31, 2015

(With 1 figure)

\begin{abstract}
The Sinos River Basin (SRB) is located in the northeastern region of the state of Rio Grande do Sul $\left(29^{\circ} 20^{\prime}\right.$ to $30^{\circ} 10^{\prime} \mathrm{S}$ and $50^{\circ} 15^{\prime}$ to $51^{\circ} 20^{\prime} \mathrm{W}$ ), southern Brazil, and covers two geomorphologic provinces: the southern plateau and the central depression. It is part of the Guaíba basin, has an area of approximately $800 \mathrm{~km}^{2}$ and contains 32 counties. The basin provides drinking water for 1.6 million inhabitants in one of the most important industrial centres in Brazil. This study describes different water quality indices (WQI) used for the sub-basins of three important streams in the SRB: Pampa, Estância Velha/Portão and Schmidt streams. Physical, chemical and microbiological parameters assessed bimonthly using samples collected at each stream source were used to calculate the Horton Index (HI), the Dinius Index (DI) and the water quality index adopted by the US National Sanitation Foundation (NSF WQI) in the additive and multiplicative forms. These indices describe mean water quality levels at the streams sources. The results obtained for these 3 indexes showed a worrying scenario in which water quality has already been negatively affected at the sites where three important sub-basins in the Sinos River Basin begin to form.
\end{abstract}

Keywords: water quality index (WQI), monitoring, Pampa stream, Estancia Velha/Portão stream, Schmidt stream.

\section{Avaliacão da qualidade da água das nascentes de arroios da Bacia do Rio dos Sinos, região sul do Brasil}

\section{Resumo}

A Bacia Hidrográfica do Rio dos Sinos (BHRS) está localizada na região Nordeste do Estado do Rio Grande do Sul $\left(29^{\circ} 20^{\prime}\right.$ to $30^{\circ} 10^{\prime} \mathrm{S}$ and $50^{\circ} 15^{\prime}$ to $\left.51^{\circ} 20^{\prime} \mathrm{W}\right)$, na região Sul do Brasil, envolvendo duas regiões geomorfológicas, o planalto Sul e a depressão central. Esta bacia faz parte da Bacia do Guaíba e tem uma área de aproximadamente $800 \mathrm{~km}^{2}$, atingindo 32 municípios. A BHRS fornece água de abastecimento para cerca de 1.6 milhões de habitantes e para um dos mais importantes centros industriais do Brasil. Este artigo apresenta a determinação de diferentes índices de qualidade de água (IQA) para as regiões de nascente de três importantes sub-bacias pertencentes à BHRS: arroios Pampa, Estância Velha/Portão e Schmidt. Utilizando parâmetros físicos, químicos e microbiológicos, analisados em amostras coletadas bimestralmente em cada ponto próximo à nascente, foram calculados os índices de Horton (IH), de Dinius (ID) e o índice de qualidade de água da National Sanitation Foundation, EUA (IQANSF) usando os métodos somatório e produtório. Os resultados foram analisados para verificação da qualidade da água nos pontos amostrais a fim de comparar e classificar a água na região das nascentes das três sub-bacias. Uma avaliação conjunta dos índices calculados indicou que a água nos três pontos amostrais apresenta qualidade média. Os resultados dos três índices convergem a um cenário preocupante que indica que, desde os pontos iniciais de formação de três importantes sub-bacias do rio dos Sinos, já ocorrem problemas de qualidade de água.

Palavras-chave: índices de qualidade de água (WQI), monitoramento, arroio Pampa, arroio Estância Velha/Portão, arroio Schmidt. 


\section{Introduction}

Changes in the amount, distribution and quality of water resources compromise the survival of human beings and other species in our planet. The economic and social development of countries is based on the availability of good quality water and the capacity to preserve and protect it (Tundisi, 2003).

The river basins in Brazil have been degraded by the disorganised growth of cities and overpopulation, as well as by several potentially harmful anthropic activities established along water courses without any planning.

The Sinos River Basin (SRB) is located in the northeastern area of the state of Rio Grande do Sul (29 $20^{\circ}$ ' to $30^{\circ} 10^{\prime} \mathrm{S}$ and $50^{\circ} 15^{\prime}$ to $\left.51^{\circ} 20^{\prime} \mathrm{W}\right)$, southern Brazil, covering two geomorphologic provinces: the southern plateau and the central depression (Figure 1). It is part of the Guaíba basin, has an area of approximately $800 \mathrm{~km}^{2}$ and contains 32 counties. The Sinos river basin, an example of an impacted watercourse, provides drinking water for 1.6 million inhabitants in one of the most important industrial centres in Brazil (Petry and Schulz, 2006). The basin covers a densely populated urban area where industrial production is highly diversified: footwear and leather, metalwork and heavy machinery, food, petrochemicals, timber and furniture, tourism and hospitality. The lower reaches of the basin are under strong anthropogenic pressure because the largest industrial park of Rio Grande do Sul is located in this region (Rio Grande do Sul, 2009; Blume et al., 2010). The main causes of degradation in the Sinos River tributaries are pollution originating from domestic and industrial sewage in urban areas, eutrophication, erosion, and the elimination of the riparian buffer strips in agricultural areas (Weber et al., 2013). Environmental impacts result from the continued overuse of water, the release of pollutants into the soil, air and water, the use of pesticides and fertilisers, the discharge of animal waste into waters, and the reduction or extinction of native flora and fauna (Macedo, 2009). Figure 1 shows the Sinos River Basin.

The monitoring of water bodies provides important information for river basin management. Such data can be used to make diagnoses of current conditions, predict future environmental outcomes and promote the sustainable development of the region. Effective monitoring should be preceded by physical, chemical and bacteriological analyses to diagnose water quality. Water quality indicators use variables that correlate them with both anthropic and natural changes in the micro-basin. Each lotic environment has specific characteristics, which makes it difficult to define a single variable as a standard indicator for any hydrological system.

Water quality is an important criterion when matching water demand to water supply. Ensuring adequate freshwater quality for both humans and ecological needs is an important aspect of integrated environmental management and sustainable development (Srebotnjak et al., 2012).

Water quality indices (WQI) are mathematical instruments that transform large quantities of data into a single number that describes water quality and summarises data into simple terms (e.g., poor, good etc.) used to consistently report findings to management and the public (Ott, 1978). Therefore, a water quality index is a communication tool to transmit information. Such information may be used by several stakeholders, from those that are closely associated with the resource to those that are distantly connected to it (e.g., the general public, users, scientists, managers, lawmakers, engineers) (Nasirian, 2007).

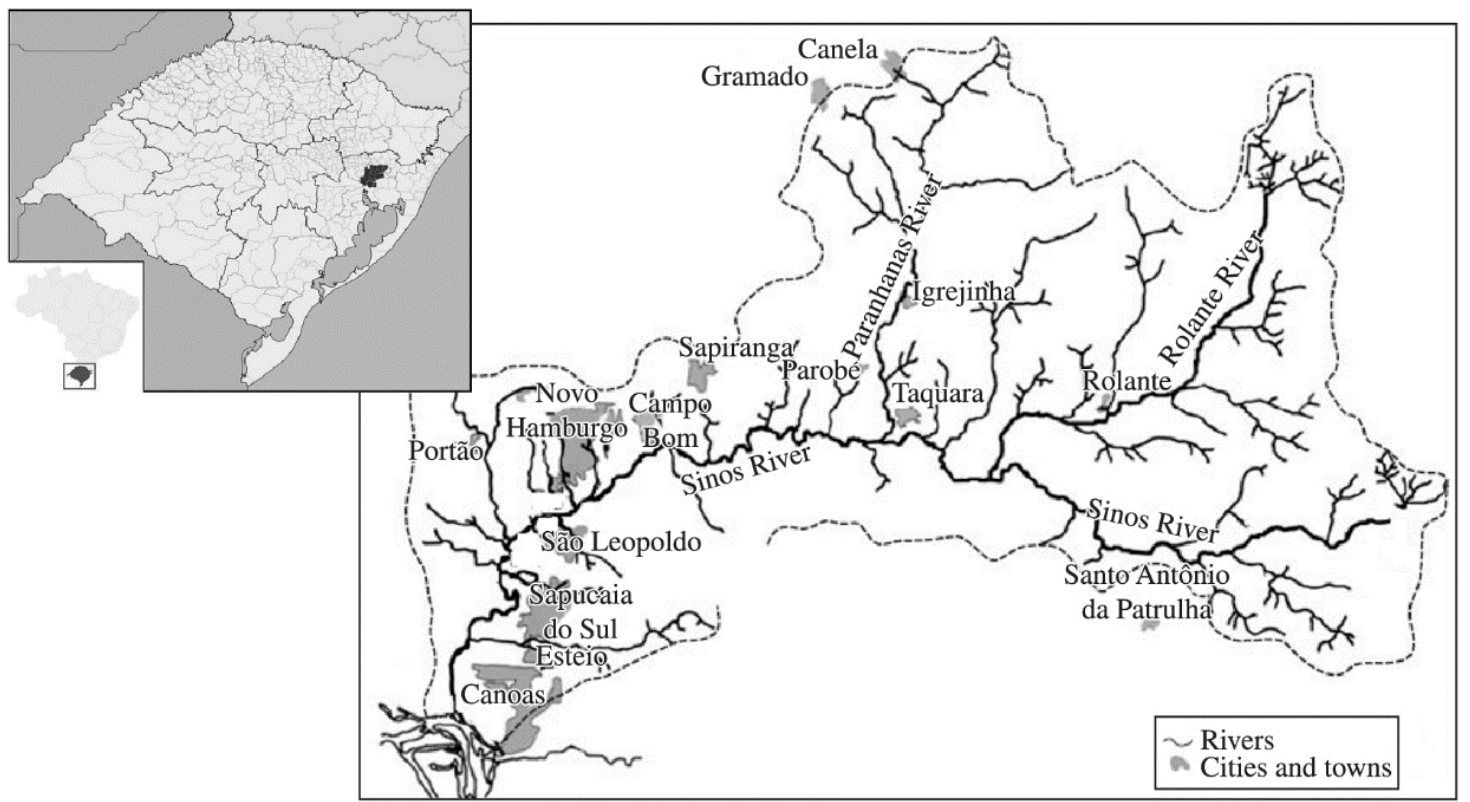

Figure 1. The Sinos river Watershed. (Rio Grande do Sul, 2010). 
WQI of different water bodies may be used for comparisons, and water quality may be analysed at different levels to define trends in quality over time (Ott, 1978; Chowdhury et al., 2012). Horton (1965) suggested that the various water quality data could be integrated into an overall index. A general WQI developed by Brown et al. (1970) was later improved by Deininger for the National Sanitation Foundation (1975) (NSFWQI). Dinius (1972) made an attempt to design a rudimentary social accounting system to measure the costs and impacts of pollution control efforts and applied that index on an illustrative basis to data about several streams in Alabama, USA. Horton's pioneering effort was followed by several WQI variations, whose use has been strongly advocated by agencies responsible for water supply and water pollution control (Bharti and Katyal, 2001). Over the years many indices have been calculated, each for its own purpose (Štambuk-Giljanović, 1999; Bharti and Katyal, 2001; Nasirian, 2007; Srebotnjak et al., 2012). The basic difference between these indices is the way that their sub-indices were developed. Despite the attention that WQIs have received in scientific and popular publications, no single, widely-accepted method has emerged. Furthermore, all indices currently used are restricted in their applicability and scope, because each author adopted different indicators, weights and sub-indices (Srebotnjak et al., 2012).

The quality indices used in this study are: NSF additive (NSFWQIa), NSF multiplicative (NSFWQIm), Horton Index (HI) and Dinius Index (DI). They were used to compare human actions that affect water resources and provide an overview of water quality at the source of three important streams in the Sinos river Basin. Results were compared to define which index provided the best representation of the actual conditions at the sampling sites and to identify the critical parameters that negatively affect water quality in the Pampa, Estância Velha/Portão and Schmidt streams.

\section{Material and Methods}

\subsection{Study sites}

The Sinos River basin (SRB) is located in the northeastern region of Rio Grande do Sul state, Brazil. The river's main stem is $190 \mathrm{~km}$ long and drains an area of about $3,820 \mathrm{~km}^{2}$, corresponding to $1.5 \%$ of the total area of the state (Rio Grande do Sul, 2009). The SRB is part of the phytogeographic region classified as Semideciduous Seasonal Forest (Teixeira et al., 1986). The climate is subtropical with four well-defined seasons (Costa and Schulz, 2010).

The Pampa, Schmidt and Estância Velha/Portão streams are in the lower region of the SRB, which is densely urbanised and has a high concentration of industries. This area receives domestic and industrial waste waters, domestic and industrial sewage, as well as huge amounts of domestic garbage (Rio Grande do Sul, 2009).

Site samples were collected close to the sources of the streams: site 1: Pampa stream (29 38'28.5'S and $51^{\circ} 06$ '39.51'W, $153 \mathrm{~m}$ alt.); site 2: Schmidt stream
(29³9'6.64"S and 51 ${ }^{\circ} 4^{\prime} 51.23$ 'W, $52 \mathrm{~m}$ alt.) and site 3: Estância Velha/Portão stream (29³8'17.06"S and 51'9'17.09'W, 67 m alt.).

\subsection{Physical, chemical and microbiological analyses}

One sample was collected from each study site, in winter and spring (2012, July to September). In situ pH, oxygen concentration, temperature, total dissolved solids and conductivity of the water were monitored. A portable multiparametric unit (YSI ADV6600 A2, SonTek) was used for measurements. Some water samples from each site were collected into sterile containers and stored at $5^{\circ} \mathrm{C}$ until analysis.

The following parameters were evaluated for all samples using the Standard Methods for the Examination of Water and Wastewater (Franson, 1998): a) total alkalinity by titrimetry; b) total phosphorus by colorimetry; c) microbial sewage pollution indicators (total and fecal coliforms and Escherichia coli (Escherichi, 1885) using enzymatic substrate method; d) chloride by titrimetry; e) nitrate concentration by colorimetry; f) colour by colourimetry; g) turbidity by nephelometry; h) total solids by gravimetry; i) hardness by titrimetry; j) chemical organic demand (COD) by titrimetry; and k) biochemical organic demand $\left(\mathrm{BOD}_{5}\right)$ by manometry.

\subsection{Water Quality Indices (WQI)}

Water quality assessment may be defined as the analysis of physical, chemical and biological characteristics of water. In this study, the Horton index (HI) (Horton, 1965), the Dinius index (DI) (Dinius, 1972) and the additive and multiplicative NSFWQI (NSFWQIa and NSFWQIm) (Brown et al., 1970) were calculated (Table 1) using physical, chemical and microbiological data (Table 2). These WQI values are dimensionless numbers in a 0 to 100 range, where 0 is the worst condition, and 100 , the highest quality. The indices calculated may be used to compare water quality at the sampling sites under study.

\section{Results and Discussion}

Table 2 shows the mean values for each site and the Brazilian standard for Class 1 freshwater (water intended for human consumption, after simplified treatment) (Brasil, 2005). According to Table 2, most parameters values are presented in the same magnitude, although the second samples were collected at a time of greater rain volume.

Table 3 shows the Horton, Dinius and NSF indices calculated from data in Table 2 according to the equations in Table 1.

As expected, Pampa had the best ratings in the three indices, followed by the Estancia Velha/Portão, whereas the Schmidt had the lowest values in the three indices. Pampa stream is the most preserved and the most difficult access site, then the conditions of the Estância Velha/Portão site, however, in the Schmidt, there are inhabitants in the region above the collection site.

NSFWQIa and NSFWQIm were numerically different, but in the same range, and the descriptor used for each 
Table 1. Water quality indices used in this study: parameters, equations, classification.

\begin{tabular}{|c|c|c|c|}
\hline Index & Parameters & Equation & Range and Classification \\
\hline $\begin{array}{l}\text { Dinius Index* } \\
\text { (Dinius, 1972) }\end{array}$ & $\begin{array}{c}\text { DO } \% \text {, Total Coliforms, Fecal } \\
\text { coliforms, COD, Chloride, } \\
\text { Conductivity, Alkalinity, } \\
\text { pH, Hardness, colour, } \\
\text { Temperature }\end{array}$ & $D I=\frac{1}{21} \sum_{i=1} w_{i} I_{i}$ & $\begin{array}{c}\text { 0-49\% - Not Acceptable } \\
50-59 \% \text { - Doubtful } \\
60-80 \% \text { - Necessary } \\
\text { treatment becoming more } \\
\text { extensive } \\
\text { 81-90\%- Minor Purification } \\
\text { required } \\
\text { 91-100\% - Purification not } \\
\text { necessary }\end{array}$ \\
\hline $\begin{array}{l}\text { Horton Index } \\
\text { (Horton, 1965) }\end{array}$ & $\begin{array}{c}\text { DO\%, Total Coliforms, } \\
\text { Sewage Treatment }(\% \\
\text { population served), } \\
\text { Chloride, Conductivity, } \\
\text { Alkalinity, pH, Settleable } \\
\text { Solids, Temperature }\end{array}$ & $\begin{array}{c}H I=\frac{\sum_{i=1}^{n} w_{i} I_{i}}{\sum w_{i}} \cdot M_{1} \cdot M_{2} \\
\mathrm{~W}_{\mathrm{i}}=\text { weight } \\
\mathrm{I}_{\mathrm{i}}=\text { sub-index } \\
\mathrm{M}_{1}=\text { Temperature factor } \\
\mathrm{M}_{2}=\text { Settleable solids factor }\end{array}$ & $\begin{array}{c}\text { 0-25 - Very poor } \\
\text { 26-50- Poor } \\
51-70-\text { Fair }\end{array}$ \\
\hline NSFWQI Additive & $\begin{array}{c}\text { DO, Fecal Coliforms, } \\
\text { BOD5, Nitrate, Phosphate, } \\
\text { pH, Turbidity, Total Solids, }\end{array}$ & $N S F W Q I a=\sum_{i=1}^{n} w_{i} \cdot I_{i}$ & $\begin{array}{c}\text { 71-90 - Good } \\
\text { 91-100-Excellent }\end{array}$ \\
\hline $\begin{array}{l}\text { Multiplicative } \\
\text { (Brown et al., 1970) }\end{array}$ & Temperature & $N S F W Q I m=\prod I_{i}^{w_{i}}$ & \\
\hline
\end{tabular}

*Dinius Social Accounting System General Rating Scale (Dinius, 1972) - range for public water supply.

Table 2. Mean values of physical, chemical and microbiological parameters of the samples collected in the sources and national standards for Class 1 freshwater.

\begin{tabular}{|c|c|c|c|c|}
\hline \multirow[t]{2}{*}{ Parameter } & Pampa stream & Schmidt stream & $\begin{array}{l}\text { Estância Velha/ } \\
\text { Portão stream }\end{array}$ & \multirow{2}{*}{$\begin{array}{c}\text { Standard (Class 1) } \\
\text { CONAMA 357/2005 } \\
\text { (Brasil, 2005) }\end{array}$} \\
\hline & Mean & Mean & Mean & \\
\hline Alkalinity $\left(\mathrm{mg} \mathrm{L}^{-1}\right)$ & $55.5 \pm 17.11$ & $34.65 \pm 12.4$ & $48.15 \pm 2.76$ & $-\mathrm{a}$ \\
\hline $\begin{array}{l}\text { Total Coliforms } \\
\left(\mathrm{MPN} 100 \mathrm{~mL}^{-1}\right)\end{array}$ & $1.41 \mathrm{E}+02 \pm 5.37 \mathrm{E}+02$ & $3.2 \mathrm{E}+04 \pm 0.4 \mathrm{E}+4$ & $3.05 \mathrm{E}+03 \pm 0.5+02$ & - \\
\hline $\begin{array}{l}\text { Thermotolerant } \\
\text { Coliforms (Fecal E. coli) } \\
\left(\mathrm{MPN} 100 \mathrm{~mL}^{-1}\right)\end{array}$ & $0.00 \mathrm{E}+00 \pm 0$ & $2.0 \mathrm{E}+03 \pm 0$ & $0.00 \mathrm{E}+00 \pm 0$ & 200 \\
\hline Chloride $\left(\mathrm{mg} \mathrm{L}^{-1}\right)$ & $4.35 \pm 2.76$ & $3.5 \pm 0.52$ & $3.85 \pm 0.07$ & 250 \\
\hline Conductivity $\left(\mu \mathrm{Scm}^{-1}\right)$ & $128.95 \pm 23.41$ & $109.68 \pm 61.01$ & $137.65 \pm 23.48$ & - \\
\hline colour $(\mathrm{uH})$ & $20.5 \pm 13.44$ & $66 \pm 37.17$ & $96.5 \pm 4.95$ & 0 \\
\hline $\mathrm{BOD}_{5}\left(\mathrm{mg} \mathrm{O}_{2} \mathrm{~L}^{-1}\right)$ & $<5,00 \pm 0$ & $6.5 \pm 4.6$ & $5.5 \pm 0.71$ & 3 \\
\hline $\mathrm{COD}\left(\mathrm{mg} \mathrm{O}_{2} \mathrm{~L}^{-1}\right)$ & $6.2 \pm 0.28$ & $6.75 \pm 4.57$ & $19 \pm 1.7$ & - \\
\hline $\begin{array}{l}\text { Hardness } \\
\left(\mathrm{mg} \mathrm{CaCO}_{3} \mathrm{~L}^{-1}\right)\end{array}$ & $57.75 \pm 18.03$ & $45.5 \pm 19.42$ & $57 \pm 8.49$ & - \\
\hline $\begin{array}{l}\text { Total Phosphorus } \\
\left(\mathrm{mg} \mathrm{L}^{-1}\right)\end{array}$ & $0.05 \pm 0.04$ & $0.05 \pm 0.01$ & $0.04 \pm 0.04$ & 0.1 \\
\hline Nitrate $\left(\mathrm{mg} \mathrm{L}^{-1}\right)$ & 1.58 & 1.35 & 0 & 10 \\
\hline $\begin{array}{l}\text { Dissolved Oxygen (DO) } \\
\left(\mathrm{mg} \mathrm{L}^{-1}\right)\end{array}$ & $8.59 \pm 1.99$ & $6.72 \pm 3.34$ & $8.01 \pm 1.72$ & $>6,0$ \\
\hline $\mathrm{DO} \%$ & $89.42 \pm 20.76$ & $69.9 \pm 34.75$ & $83.33 \pm 14.36$ & - \\
\hline $\mathrm{pH}$ & $6.76 \pm 0.39$ & $7.28 \pm 0.35$ & $7.23 \pm 0.11$ & 6 a 9 \\
\hline Total Solids (mg L $\left.{ }^{-1}\right)$ & $328.9 \pm 234.9$ & $174.5 \pm 6.36$ & $185.2 \pm 101.54$ & - \\
\hline Turbidity (NTU) & 32.4 & 25.2 & 41.4 & 40 \\
\hline Temperature $\left({ }^{\circ} \mathrm{C}\right)$ & $15.1 \pm 1.21$ & $17.97 \pm 2.11$ & $14.77 \pm 1.05$ & $<40$ \\
\hline
\end{tabular}

a: no value fixed as standard. 
stream was the same. Both were calculated according to the recommendations made by Landwehr and Deininger (1976) to avoid problems, such as masked results, which might occur when the sub-index shows water quality values extremely low. The National Sanitation Foundation (NSF) uses a function of the geometric mean, which is more sensitive than the arithmetic mean depending on changes in individual variables (Bharti and Katyal, 2001). According to the NSFWQI, the water in the Pampa and Estância Velha/Portão streams was classified as "good quality", whereas in the Schmidt stream, quality was "medium".

All streams had similar Horton indices, and the analysis of samples showed that the water at the sources of the three streams was of "medium quality". The Dinius index was different from the others, which suggests that it may be more accurate or include more critical parameters than the Horton and the NSFWQI indices. The analysis of quality for public water supply parameter, according to Dinius, 1972, revealed that the water in the regions close to the source of the streams under study was classified as "doubtful" in the Pampa, Estância Velha/Portão and Schmidt streams.

Temperature, $\mathrm{pH}$ and dissolved oxygen (DO) are parameters used to calculate DI, HI and NSFWQI. The values found for all streams were acceptable, and $\mathrm{pH}$ and temperature were not responsible for differences between the indices of the sources under study. However, DO was slightly lower in the Schmidt stream than in the other streams and was responsible for the first difference between DI, HI and NSFWQI.

Colour, turbidity and solids were found in all samples and they are explained by bed sediment transport in the beginning of the stream formation. Visible sediment transport was found mainly at sites 2 (Schmidt stream) and 3 (Estância Velha/Portão stream). Solids and turbidity are not critical values for the calculation of NSFWQI; for HI, solids are a critical value only if they correspond to apparent pollution, which was not the case in the sampling sites under study. Colour is a minor parameter in DI calculation, but the highest value found in site 3, followed by site 2 (Table 2), indicates a new difference between final DI values at the sampling sites, although all sampling sites were classified as doubtful for public water supply (Dinius, 1972) (Table 3).

The presence of organic matter was explained by, among other factors, the semideciduous vegetation in the region of the sources under study. Reports by local inhabitants suggest contamination by sewage in the Schmidt stream. There are houses above the point selected as a sampling site in the region close to the Schmidt stream source, which may increase the organic load in the watercourse. In this study, $\mathrm{HI}$ did not use $\mathrm{COD}$ and $\mathrm{BOD}_{5}$ as parameters, whereas COD was a fairly important parameter in the calculation of DI (Table 2). The highest COD concentration was found at the source of the Estância Velha/Portão stream, followed by the Schmidt stream, where the value was greater than that found for the Pampa stream. This is the third factor to explain why DI had the worst evaluation for samples, and this result suggests that DO, colour and COD were critical parameters for the samples collected in the Schmidt and Estância Velha/Portão streams.

NSFWQI includes $\mathrm{BOD}_{5}$, which was responsible for the first difference in NSFWQI, although its weight is low. The best conditions were found in the Pampa and Estância Velha/Portão streams, where quality was classified as good, whereas the water in the region close to the Schmidt stream source had the poorest quality. Table 3 shows that the Schmidt stream had medium quality water.

The sampling sites at the Pampa and Estância Velha/Portão streams had no thermotolerant coliforms (E. coli) in either sample, which showed that the location of the source, in rugged terrain surrounded by native vegetation and difficult to reach, preserved its water quality. The Schmidt sampling site, farther from the waterhole, had fecal contamination even in the beginning of the stream in the study region.

This finding confirms reports that suggest that houses above the sampling site might have contributed to contamination because of discharges of domestic sewage without proper treatment at a site near the beginning of the stream. According to Table 1, this parameter is used to calculate DI and NSFWQI. Fecal coliforms had a high weight in the calculation of both indices. The lowest DI and NSFWQI values were found in the Schmidt stream, the only stream that had fecal coliforms (according to Table 2).

A similar result was observed for total coliforms, and the Pampa stream values were lower than those found in the Estância Velha/Portão and Schmidt streams. During the study, a large amount of rain may have contributed to the increased occurrence of coliforms by soil leaching and contaminant transport (Bagde and Rangari, 1999). HI uses total coliforms to evaluate water quality. As total coliforms were greater than 20 more probable number/100 millilitres

Table 3. Water quality indices calculated using mean values of samples collected at the stream sources.

\begin{tabular}{ccccccc}
\hline WQI & $\begin{array}{c}\text { Pampa } \\
\text { stream }\end{array}$ & Classification & $\begin{array}{c}\text { Schmidt } \\
\text { stream }\end{array}$ & Classification & $\begin{array}{c}\text { Estância Velha/ } \\
\text { Portão stream }\end{array}$ & Classification \\
\hline HI & 64.71 & Fair & 60.00 & Fair & 64.71 & Fair \\
DI* & 54.20 & Doubtful & 50.45 & Doubtful & 50.18 & Doubtful \\
NSFWQI & 81.68 & Good & 67.59 & Fair & 83.18 & Good \\
$\begin{array}{c}\text { additive } \\
\text { NSFWQI }\end{array}$ & 85.21 & Good & 62.66 & Fair & 86.22 & Good \\
multiplicative & & & & & & \\
\hline
\end{tabular}

*The Dinius Index value was classified according to the range of public water supply.2010). 
(MPN/100 mL) of sample, this parameter had the same weight in the calculation of values for the Pampa, Schmidt and Estância Velha/Portão streams. DI also uses total coliforms, and the lowest indices values were obtained at the sources of the Schmidt and Estância Velha/Portão streams.

Another associated parameter, included in HI, was sewage treatment, and the percentage of population served is used in the equation. Of the cities included in this study, only Novo Hamburgo and Estância Velha have a sewage treatment plant, which, however, serves less than $2 \%$ of the population in each county. As the sub-index for sewage treatment is zero for values below $10 \%$, this parameter was not responsible for any differences in the HI calculation for the three streams.

$\mathrm{HI}$ and DI also include chloride, conductivity and alkalinity in their calculation. Table 2 shows that these three parameters had similar values for all studied streams and were not responsible for any considerable differences in the index numbers. DI also includes hardness, which had similar results for the sampling sites in the 3 streams, as for the parameters described above.

NSFWQI includes nitrate and phosphate in the evaluation of water quality. The associated parameters nitrogen $(\mathrm{N})$ and phosphorus $(\mathrm{P})$ result mainly from the discharge of untreated domestic sewage and agricultural activities. They are important nutrients that cause eutrophication (Dodds, 2006), but were not responsible for any substantial differences in the final values of NSFWQI of the samples collected.

The comparison of the values in Table 2 reveals that few parameters are above the limits defined by the CONAMA Resolution 357 (Brasil, 2005). The Schmidt stream had the lowest NSFWQI; although its samples were classified as medium quality, the number of thermotolerant coliforms (fecal coliforms, E.coli) was ten times greater than the acceptable limit. The Pampa stream had no values above the standard, and for the Estância Velha/Portão stream, only turbidity was above the limit. However, as the weight of this parameter is lower than that of coliforms, for example, this excessive turbidity did not affect the index substantially.

A general evaluation is in agreement with the conclusion reached by Srebotnjak et al. (2012): "no single widely accepted method has emerged and furthermore, all currently used indices are restricted in their applicability and scope, because each author adopted different indicators, weights and sub-indices."

Our study evaluated sources of streams or sites close to the sources, and, therefore, we expected all samples from the three sampling sites to have an excellent quality, and all parameters under analysis to be below the limits for Class 1 freshwater (Brasil, 2005). However, the evaluation of the estimated indices revealed that all stream sources tended to be classified as medium quality.

NSFWQI was fairly representative of the actual conditions of water quality because it assigned a high weight to the parameter that best indicates recent contamination by domestic sewage (Merlo et al., 2011). Also, water was classified as of medium quality in the Schmidt stream because of the presence of thermotolerant coliform (fecal, E.coli), whereas water at the other sites was classified as being of good quality.

HI was consistent with NSFWQI according to the parameters adopted and the three sampling sites were classified as of medium quality. The calculation of this index included number of total coliforms, and the values found in the three sites ranged from $10^{2}$ to $10^{4}$, which showed that this parameter had an equal weight in calculation.

DI included the greatest number of variables (11) and had the lowest values for the three sampling sites. These values, however, remained in the range that defines water quality as doubtful for public water supply, despite the fact that most parameters under evaluation corresponded to Class 1 freshwater according to the CONAMA Resolution 357 (Brasil, 2005).

The results of water parameters in the SRB revealed a higher degree of deterioration in water samples from sites closer to the sources of the basin, mainly due to the significant influence of human activity in this area. The indices showed that the reduction in water quality was associated with pollution due to untreated domestic sewage. High levels of fecal coliforms reflect the large deficit in sanitation in the area of the basin, especially in lower reaches of the SRB.

\section{Conclusion}

Each index uses different parameters to evaluate water quality. NSFWQI provided a good representation of the actual conditions of the three sampling sites. HI showed that water quality in the Pampa and Estância Velha/Portão streams was good, but it also pointed to other parameters, also important, which showed that the waters were of medium quality. As an index to classify public water supply, DI revealed the doubtful quality in the three sampling sites.

The results of the three indices converged to a worrying scenario in which the sites of the initial formation of three important sub-basins in the Sinos river basin already have water quality that is less than optimal. The use of these evaluation indices along all the length of the streams under study and the use of other indices, as well as the future development of a specific index for the SRB, may contribute to raising awareness and developing management tools to improve water quality in these water bodies and in the entire basin.

The sources and the initial stretches of streams are severely affected by human activities. These areas require better management and the implementation of projects to raise environmental awareness among the community, improve preservation, and ensure effective monitoring by authorities.

\section{Acknowledgements}

This study was financially supported by FINEP, FAPERGS, CNPq and CAPES. 


\section{References}

BAGDE, JS. and RANGARI, AK., 1999. Periodicity of coliform bacteria in an aquatic environment. Water Science and Technology, vol. 40 , no. 7 , p. 151-157.

BHARTI, N. and KATYAL, D., 2001. Water quality indices used for surface water vulnerability assessment. International Journal of Environmental Sciences, vol. 2, no. 1, p. 154-173.

BLUME, KK., MACEDO, JC., MENEGUZZI, A., SILVA, LB., QUEVEDO, DM. and RODRIGUES, MAS., 2010. Water quality assessment of the Sinos River, Southern Brazil. Brazilian Journal of Biology $=$ Revista Brasileira de Biologia, vol. 70, no. 4, supplement, p. 1185-1193. http://dx.doi.org/10.1590/S151969842010000600008. PMid:21225160

Brasil. Conselho Nacional do Meio Ambiente, 2005. Resolução $n^{o} 357$ de 03/2005. Dispõe sobre a classificação dos corpos de água e diretrizes ambientais para o seu enquadramento, bem como estabelece as condições e padrões de lançamento de efluentes, $e$ dá outras providências. Diário Oficial da União, Brasília, 18 mar. p. 58-63. Available from: <http://www.mma.gov.br/port/conama/ res/res05/res35705.pdf>. Access in: 10 Nov. 2012.

BROWN, RM., MCCLELLAND, NI., DEININGER, RA. and TOZER, RG., 1970. A water quality index: do we dare? Water \& Sewage Works, vol. 117, p. 339-343.

CHOWDHURY, RM., MUNTASIR, SY. and HOSSAIN, MM. 2012. Water Quality Index of water bodies along Faridpur-Barisal Road in Bangladesh. Global Engineers \& Technologists Review, vol.2, no. 3, p.1-8.

COSTA, PF. and SCHULZ, UH., 2010. The fish community as an indicator of biotic integrity of the streams in the Sinos River basin, Brazil. Brazilian Journal of Biology = Revista Brasileira de Biologia, vol. 70, supplement 4, p. 1195-1205. http://dx.doi. org/10.1590/S1519-69842010000600009. PMid:21225161

DINIUS, SH., 1972. Social accounting system for evaluating water resources. Water Resources Research, vol. 8, no. 5, p. 1159-1177. http://dx.doi.org/10.1029/WR008i005p01159.

DODDS, WK. 2006. Eutrophication and trophic state in rivers and streams. Limnology and Oceanography, vol. 51, no. 1, part 2, p. 671-680.

FRANSON, MAH., 1998. Standard methods for the examination of water and wastewater. 20th ed. Washington: American Public Health Association.

HORTON, RK., 1965. An index-number system for rating water quality. Journal - Water Pollution Control Federation, vol. 37, no. 3, p. 300-306.

LANDWEHR, JM. and DEININGER, RA., 1976. A comparison of several water quality indexes. Journal - Water Pollution Control Federation, vol. 48, no. 5, p. 954-958.

MACEDO, JC., 2009. Monitoramento da qualidade das águas do Rio dos Sinos. Novo Hamburgo: Centro Universitário Feevale, 184 p. Masters Dissertation.
MERlo, C., ABril, A., AMÉ, MV., ARGÜEllo, GA., CARRERAS, HA., CHIAPPERO, MS., HUED, AC., WANNAZ, E., GALANTI, LN., MONFERRÁN, MV., GONZÁLEZ, CM. and SOLÍS, VM., 2011. Integral assessment of pollution in the Suquía River (Córdoba, Argentina) as a contribution to lotic ecosystem restoration programs. The Science of the Total Environment, vol. 409, no. 23, p. 5034-5045. http://dx.doi.org/10.1016/j. scitotenv.2011.08.037. PMid:21925711

NASIRIAN, M., 2007. Anew water quality index for environmental contamination contributed by mineral processing: a case study of amang (Tin Tailing) processing activity. Journal of Applied Sciences., vol. 7, no. 20, p. 2977-2987. http://dx.doi.org/10.3923/ jas.2007.2977.2987.

OTT, WR., 1978. Water Quality Indices: a survey of indices used in the United States. Washington: U.S. Environmental Protection Agency Office of Research and Development.

PETRY, AC. and SCHULZ, UH., 2006. Longitudinal changes and indicator species of the fish fauna in the subtropical Sinos River, Brazil. Journal of Fish Biology, vol. 69, no. 1, p. 272-290. http:// dx.doi.org/10.1111/j.1095-8649.2006.01110.x.

Rio Grande do Sul. Secretaria Estadual do Ambiente e Desenvolvimento Sustentável-SEMA, 2009. Fundação Estadual de Proteção Ambiental Henrique Luis Roessler. SEMA. Available from: $<$ http://www.fepam.rs.gov.br>. Access in 12 Dez. 2012.

Rio Grande do Sul. Secretaria Estadual do Ambiente e Desenvolvimento Sustentável - SEMA, 2010. Portal do Meio Ambiente RS. Bacia Hidrográfica do Rio dos Sinos. SEMA. Available from: $<$ http://www. sema.rs.gov.br/conteudo.asp?cod_menu $=56 \&$ cod_conteudo $=5865>$. Access in 14 Jan. 2013.

SREBOTNJAK, T., CARR, G., SHERBININ, A. and RICKWOOD, C., 2012. A global Water Quality Index and hot-deck imputation of missing data. Ecological Indicators, vol. 17, p. 108-119. http:// dx.doi.org/10.1016/j.ecolind.2011.04.023.

ŠTAMBUK-GILJANOVIĆ, N., 1999. Water quality evaluation by index in Dalmatia. Water Research, vol. 33, no. 16, p. 3423-3440. http://dx.doi.org/10.1016/S0043-1354(99)00063-9.

TEIXEIRA, MB., COURA NETO, AB., PASTORE, U. and RANGEL FILHO, ALR., 1986. Vegetação. As regiões fitoecológicas, sua natureza e seus recursos econômicos. Estudo fitogeográfico. In Instituto Brasileiro de Geografia e Estatística - IBGE (Ed.). Levantamento de recursos naturais. Rio de Janeiro: IBGE. vol. 33 , p. 541-632

TUNDISI, JG., 2003. Recursos hídricos. MultiCiência, vol. 1, p. $1-15$.

WEBER, P., BEHR, ER., KNORR, CL., VENDRUSCOLO, DS., FLORES, EMM., DRESSLER, VL. and BALDISSEROTTO, B., 2013. Metals in the water, sediment, and tissues of two fish species from different trophic levels in a subtropical Brazilian river. Microchemical Journal, vol. 106, p. 61-66. http://dx.doi. org/10.1016/j.microc.2012.05.004. 